\title{
Ibn Warraq Vakası: “Self-Kolonizasyon" İçin Mütevazı Bir Kavramsallaştırma Denemesi
}

\author{
Gökdemir İhsan*
}

\section{Giriş}

Doğu ve Batı hakkında konuşmaya başlar başlamaz, hâkim akademik söylem bizden bir hususta hemen şahadet getirmemizi bekler: Allah sizi inandırsın ki Doğuya ve Batıya mutlak birer varoluş atfeden "özcü" bir yaklaşımdan uzağız ve Oryantalizm karşısında Oksidentalist bir tavır falan aldığımız da yok! Bu obligation à dire ${ }^{1}$ akla antisemitik yemin tazelemeyi getiriyor: İsrail'in o azgın saldırganlığını en hafif bir eleştirinin dahi konusu yapmaya kalktığınızda, bir antisemit olmadığınızı yemin billah kanıtlamak zorundasınızdır. Art arda gelen bu çağrışım aslında ilgisiz iki meselenin ironik benzerliğinden öte bir anlam da taşıyor: Neo-kolonyalistler kendilerine yeni düşman olarak İslam'ı seçip, her türlü kötülüğün isminin önüne onun ismini ekledikçe, İsrail, Filistin üzerindeki katliamlarını rahatılıkla sürdürebiliyor. Said'in Haberlerin Ağında İslam'da belagatle izah ettiği gibi, Batı ve Amerikan medyasında "İslam", "fundamentalizm" ve "terör" kavramları yan yana ve hatta birbirinin eşdeğeri olarak kullanıldıkça, "haklı İsrail" imgesi giderek güçleniyor.

Bu aşırı hızlı giriş, bize hem üstüne konuşacağımız meselelerin güncel arka planını veriyor hem de —bir iki eksikle de olsa - yazının çerçevesini çiziyor. Girişten de anlaşıldığı üzere, bu yazı neo-kolonyalizm, Edward Said, oryantalizm, oto-oryantalizm ve İslam gibi kavramların etrafında dolaşacak. Aslında yukarıdaki paragrafa, bir yolunu bulup Ibn Warraq adını da sıkıştırabilseydik, çerçeve eksiksiz çizilmiş olurdu. Ya da kitabının adını ansaydık; zira kendisinin eleştirimizde mühim bir yer teşkil edecek olan Said ve Saidciler ya da Üçüncü Dünya Entelektüel Terörizmi (2003) başıılı makalesindeki görüşlerini genişleterek yazdığı kitabının adını anmak bile, ne ile karşı karşıya olduğumuzu özetlemeye yetiyor: Defending the West: $A$ Critique of Edward Said's Orientalism (2007).

\section{Ibn Warraq}

Bugün Batıda, ülkesinden kaçmak zorunda kalmış ya da sürülmüş onlarca muhalif doğulu aydın yaşasa da, inşa etmeye çalıştığı beceriksiz külliyatı, şedit üslubu ve bilhassa Said'i eleştirmeye çalıştığı mezkûr makalesiyle, Ibn Warraq dikkatimizi çekmeyi başararak, tarif etmeye çalışacağımız "self-kolonizasyon" kavramının şahsında tecessüm ettiği kişi olarak temayüz ediveriyor.

* E-posta: gokdemir.ihsan@gmail.com Adres: Merkez Efendi Mah. Mevlana Cad. No: 140/A Toya Plaza Kat: 4 Zeytinburnu, istanbul.

1 «Le fascisme, ce n'est pas d'empêcher de dire, c'est d'obliger à dire.» (Barthes) 
1946'da Hindistan'da Müslüman bir ailenin üyesi olarak doğan Ibn Warraq², Pakistan kurulduğunda ailesiyle birlikte oraya göç eder. Daha sonra eğitimi için Britanya'ya gider. Edinburgh Üniversitesi'nde felsefe ve Arapça eğitimi alır. Bir süre Londra'da ilkokul öğretmenliği yaptıktan sonra, Fransa'ya giderek bir Hint restoranı açar. Salman Rushdie olayı meydana gelene kadar bir seyahat acentesinde çalışır. Bu olay vesilesiyle, Amerikan Free Inquiry dergisinde "Why I am not a Muslim"33 başlığında yazmaya başlar. Kuran ve Hazreti Muhammed'e yönelik hücumlar içeren birçok çalışma yayımlar. 2006 yılında (en ünlüsü Salman Rushdie olan) on bir imzacıyla birlikte, Hazreti Muhammed karikatürlerine karşı İslam dünyasından yükselen protestolara cevaben "Together facing the new totalitarianism" başlıklı manifestoyu yayımlar. 2007'de ise Defending the West: A Critique of Edward Said's Orientalism adlı kitabı yayımlanır. Institute for the Secularisation of Islamic Society'nin kurucusu olan Ibn Warraq, 2007'de St. Petersburg'da düzenlenen Seküler İslam Zirvesine katılarak, kendilerine İslam reformcuları adını veren, Müslüman ülkelerden göç etmek durumunda kalmış bir grup göçmenle birlikte, şeriat hukukunu, mahkemelerini, ruhban sınıfını ve lafz-ı küfür ve irtidata uygulanan cezaları reddettiklerini açıklayan St. Petersburg Deklarasyonunu yayımlar. Yazılarına elan The Wall Street Journal ve The Guardian'da rastlanabilen Ibn Warraq, çeşitli vesilelerle Batı dünyasının önemli devlet adamlarına hitap etmektedir.

\section{Kavramsal Yaklaşım}

\section{Tenzih}

Önümüzde muazzam bir post-kolonyal eleştiri külliyatı olduğu halde, self-kolonizasyon kavramını yeniden tanımlamak zorunda oluşumuz, onun yeni ve benzersiz karakterinden kaynaklanmaktadır. Self-kolonyalizmi tanımlamadan önce onu tanıdık kavramlardan tenzih etmeye çalışalım. Self-kolonyalizm neo-kolonyalizmle aynı şey değildir. Çünkü onun öznesi kolonyal güçler değil, bizzat sömürge aydınıdır. Self-kolonizasyon neo-kolonyalizmin bir bileşeni olsa da, onun ideolojisi kolonyal dönemden tanıdığımız, "sömürgecinin hizmetindeki sömürge aydını"nın ideolojisinden farklıdır. O artık, Cemil Meriç'in beliğ ifadesiyle, "sudaki aksinden tiksinen narsist" olmayı çoktan geride bırakmıştır. Sömürge aydınının o eski bakışında, Batılıya benzemeyişinin yarattığı öz-aşağılama duygusunun yanı sıra, ısrarla bu hale müstahak olmadığını yineleyen narsistik bir iç ses de vardı. Oto-oryantalizm olarak isimlendirebileceğimiz bu bakış, sömürgecilerin tüm vahşetine payanda olmasına rağmen, çocuksu bir naiflik de taşıyordu. Bizde "Bihruz Bey"le, ama daha derinlikli bir tahlille Dostoyevski'nin "Yeraltı adamı"yla temsil edilen bu karakter, çocuksu bir milliyetçiliğe sahipti. Tanzimat aydınında görülen, din değiştirmeyi bile teklif etmekten kaçınmayan bu çocuksuluk, "milletinin bu zillete layık olmadığına", bir an önce bu halden kurtularak "medeni dünyada hak ettiği yeri" alması gerektiğine dair içten bir inançtan kaynaklanıyordu. Oto-oryantalist, kendisini Batılının gözünden seyrederek tiksinse de, Batılıya benzeyerek bu halden kurtulabileceğini düşünür. Oysa self-kolonyalist toplumuna dinini değiştirmeyi ya da reforme etmeyi önermez; onu tahrip etmeye ve yok etmeye çalışır. Ibn Warraq'ın kurucusu olduğu enstitü her ne kadar kendisini İslam toplumunun sekülarizasyonuyla

2 Kimilerince Mutezile'den ayrılarak Dehriye olarak tabir edilen materyalist ekolü kurduğu iddia edilen İbn Ravedeni'nin hocası Ebû İsa el-Varrak'tan mülhem, "Kağıtçının oğlu” anlamındaki ismi müsteardır.

Aynı başlıkla bir de kitap yayımlamıştır. Bkz. Warraq 1995. 
görevli kılsa da, Ibn Warraq sekülarist bir İslam yorumunun peşinde değildir. İslam, dünyevi iddialarından arındırılıp "Ilımlı" bir hale getirilse de, hatta Müslümanlar topyekûn İslam'ı terk edip Ibn Warraq gibi agnostik ${ }^{4}$ olsalar da yetmez. Ona göre şiddetin, terörün, ırkçılığın, antisemitizmin, dogmatizmin ve anti-demokrasinin kaynağı olan İslam yok edilmelidir. Why am Inot a Muslim'e Ibn Warraq, E. Renan'dan bir alıntıyla başlar: "Müslümanlara verilebilecek en iyi hizmet, onları dinlerinden kurtarmaktır." (1995)

Ibn Warraq Müslüman toplumlarda teşhis edilebilecek sorunları tarihsellikten kopararak özcülük yapar. Bu halin İslamın bir yorumundan ya da Müslüman toplumların tarihin bir anındaki koşullarından değil, bizzat İslamın kendisinden kaynaklandığını savunur. Böylelikle Müslümanlara kendilerini değiştirebilme, kendi kendilerini reforme etme fırsatını da tanımaz. Yere göğe sığdıramadığı Reform'a paralel bir sola scriptura'ya da imkân vermez. Bir söyleşisinde şöyle diyor:

Elbette ılımlı, toleranslı Müslümanlar da var. En toleranslı olanlar, daha az eğitimli olup, zor Arap lisanını okuyamadıkları için Kuran'da ne yazdığını tam olarak bilemeyenler. Eğitimli olanlar, ya da hiç olmazsa Kuran'ı okuyabilecek durumda olanlar daha toleranssızlar. Çünkü onlar Kuran'ı sözcüğü sözcüğüne algılıyorlar. (Warraq, 2007)

Self-kolonizasyon kavramının kullanıldığı bir çalışmayı, kavramdan bizim ne anladığımızı sarahate kavuşturması bakımından alıntılayalım:

Masaki kolonyal dönem Japonunu "Batılı gözlükleriyle" körleşmiş ve aldanmış olarak tarif eder. Komori Yōichi ise onların "self-kolonizasyon"ları hakkında bilinçsiz olduklarını iddia etmek için, Freudyen kavramlar olan "bilinçdışı" ve "bastırma"yı kullanır. Post-kolonyal adlı kitabında, Japonya'nın aydınlanmasını ve medenileşmesini bir selfkolonizasyon süreci olarak tanımlar: Japonya kolonizasyon kaderinden kurtulmak ve Batılı milletler tarafından "barbar" ve medenileşmemiş olarak görülmekten kaçmak için, kendini tehditkâr bir ötekinin (Batılı güçler) imgesinde yeniden yaratımıştır. Daha sonra, bu self-kolonizasyonu "bilinçdışı"na bastırarak, onları kolonize etmenin bir bahanesi olarak, Japonya kendi komşularına yönelen içselleştirilmiş bir Batılı bakışı benimsemiştir. Sürekli, sınırlarının dışında yeni "barbarlar" keşfederek Japonya, kendisinin "medenileşmiş" dünyanın bir üyesi olduğunu teyit etmiştir. (Tierney, 2005)

Burada self-kolonizasyon olarak adlandırılan şeye biz yukarıda oto-oryantalizm dedik. Bunun bir benzerine bizde, kendisini Batının gözüyle yeterince aşağılayıp "beyazladıktan" sonra, Kürtlerin ya da Arapların "barbarlık"larını keşfeden Türk'te görürüz. Ya da Hint faşistlerini Müslümanlara karşı katliamda cesaretlendiren Naipaul'da. Nobel ödüllü bu oto-oryantalist yazar, sonunda Hindulardaki medeniyeti keşfetmiştir. Ah bir de şu barbar Müslümanlar olmasa!

\section{Teşbih}

Self-kolonyalizm söylem olarak oto-oryantalizme değil, modası geçmiş bir oryantalizme yakındır. Ibn Warraq, Why I am not a Muslim'de onun eskimiş, post-kolonyal eleştiriyle geri döndürülemez biçimde tarihin çöp sepetine gönderilmiş argümanlarını cehaletle tekrar eder. On dokuzuncu yüzyıl ve öncesinde Batıda görülen İslam eleştirilerini ya aynen aktarır ya da acemice yeniden üretir. Önce İslam'ın özgün bir öğretisi olmadığını ispat etmeye çalı- 
şır. Sonra İslamın kaynaklarının ne kadar çürük ya da şüpheli olduğunu göstermeye: Hadis ve sünnetin güvenilmez kaynaklar olduğunu açıkladıktan sonra, sıra Hazreti Muhammed'in tarihsel bir kişilik olarak var olmadığının ispatına gelir. Kuran da bu "âlimane" saldırıdan payını alır: Anlatıbilim hiç icat edilmemiş gibi davranarak, Kuran'da konuşan ses ve Allah'ın ayrılığından hareketle, Kuran'ın Allah'ın sözü olmadığını ispat ediverir Ibn Warraq. Aslında sıralama değişmez; hemen sonra Kuran'ın kitap haline getirilişindeki "çelişkiler" listelenir. Sonra da sıra, tahmin edileceği üzere, eklenen ve çıkartılan ayetlere gelir. Ortaçağ Hıristiyan kültürünün ve Rönesans'ın Müslümanlara bir borcu olmadığını, İslam'ın Helenizm ve Batı arasında sadece bir aracı olduğunu ispatlamak üzere tekrar Renan'ı yardıma çağırır Ibn Warraq.

Self-kolonyalistler sömürgecilerle olan ilişkilerinde de oryantalistlere benzer. Aynı onlar gibi, sömürgecilerle organik ilişkiler kurmaktan çekinmezler. Ibn Warraq ve arkadaşlarının Batılı devlet adamları nezdindeki itibarını ve el üstünde tutuluşlarını bir tarafa bırakıp bir tek olguyu ele almakla dahi bu organik ilişki gözler önüne serilebilir. Yukarıda bahsettiğimiz St. Petersburg Deklarasyonunun yayımlandığı Seküler İslam Zirvesine ev sahipliği yapan kuruluşa kabaca bir göz attığımızda, bu kuruluşun İslam'ın sekülarizasyonuyla nasıl bir ilgisi olduğu anlaşılamıyor. Daha doğrusu, asıl niyetlerinin ne olduğu açıça anlaşılıyor. Bir komplo teorisyeni ya da amatör bir casus olmaya gerek kalmadan, zirveye ev sahipliği yapan The Intelligence Summit'in web sitesine şöyle bir göz atmakla, bu kuruluşun kurucularının ve yöneticilerinin büyük bir kısmının Amerikan ordusu ve istihbaratından emekli "sivil"lerden oluştuğunu anlıyoruz; Amerika dışından gelenlerin ise MOSSAD ya da İngiliz istihbaratından emekliye ayrılmış "sivil"ler olduğunu.

\section{Tahlil}

Self-kolonyalizmi temsilen ele aldığımız Ibn Warraq'ın eserine hâkim olan birkaç hususu sergileyerek onu tahlil etmeye çalışalım. Bunu yaparken Ibn Warraq'ın Said ve Saidciler ya da Üçüncü Dünya Entelektüel Terörizmi başlıklı makalesi bize yardımcı olacak. Ibn Warraq'ta ilk göze çarpan şey o şedit polemikçi üslubuna rağmen gizleyemediği entelektüel kofluktur. Ele aldığı hiçbir meselede, lisede felsefe ya da sosyoloji okumuş bir gençten daha üstün bir entelektüel performans gösteremez. Son birkaç yüzyıl boyunca akademiyi ve entelijansiyayı meşgul eden düşünürlerin üstünü tek kalemde çizmekten çekinmez: "Bütün insan etkinliklerini sırasıyla para, cinsellik ve iktidara indirgeyen indirgemeci Marksçılar, Freudcular ve emperyalizm karşıtları, çıkardan bağımsız zihinsel sorgulama kavramını, bilgi için bilginin ardına düşmeyi anlamakta güçlük çekerler." (Ibn Warraq, 2003) Bu yaman eleştirilerinden Foucault da payını alır: "Said, bu 'hercai' karışıma Foucault'yu ekler; Fransız guru, Şarkiyatçı araştırmaların, 'söylem' adını verdiği ideolojik çerçeve içinde gerçekleştiğine inandırmıştır Said'i." (Ibn Warraq, 2003) Hem üsluba hem de içeriğe hâkim olan bu cesaret ancak cehaletten kaynaklanır. Bu öyle bir cehalettir ki düştüğü durumun farkına varmaktan bile aciz kılar onu. Başka hiçbir referansa ihtiyaç duymadan, sadece kendi metni üzerinden dahi değerlendirildiğinde haksız olduğunu anlamamakla kalmaz, bir de Said'i tarihi çarpıtmakla suçlar:

Fransız ve İngiliz Şarkiyatçılarının emperyalistlere bir biçimde zemin hazırladıklarını öne sürmek, tarihi ciddi biçimde çarpıtmak demektir. Fransa'da ilk Arapça kürsüsü 1538 'de Collège de France'da kurulmuştur, buna karşılık bir Arap ülkesine yönelik ilk Fransız girişimi 1798 yılında Napolyon'unkidir. İngiltere'de, ilk Arapça kürsüsü 1633'te Cambridge'de kurulmuştur, buna karşılık bir Arap ülkesine ilk Ingiliz saldırısı on dokuzuncu yüzyıla kadar gerçekleşmemiştir. (Ibn Warraq, 2003) 
Bir ortaokul öğrencisinin dahi rahatlıkla tespit edebileceği kadar açıklıkla kendi tezinin aksine argüman ürettiğinin farkına bile varmaz ve safça şu soruyu ekler: "Şarkiyatçılarla Emperyalistler arasındaki suç ortaklığı nerededir burada?" Ibn Warraq muarızının seviyesi ortaokulu aştığında anlaşıımazlıktan şikâyet eder, zamanımızın modasına uyarak, her anlamadığı şeye aynı yaftayı vuranların yolunu izleyerek, onu post-modernlikle yaftalar: “Yazımda göstereceğim üzere, Said'in nüfuz edilmesi güç, 'temsili söylem evreni,' 'Şarkiyatçı söylem' gibi postmodern terimlerle bezeli düzyazısında birbiriyle çelişen çeşitli tezler ve çoğu zaman sıradan bir gözlem içeren gösterişli bir dil -tüm kastettiği 'kitabi' ya da 'kitabilik' iken, 'metinsel tutum'dan söz ettiğinde olduğu gibi- söz konusu." (Ibn Warraq, 2003)

Ibn Warraq'ın eserlerindeki eklektizm, faaliyetlerine de damgasını vurur. Onun ne için çabaladığı, kendi söylemine bakarak anlaşılamaz. İslam'ın sekülerleşmesi için mi çabalıyorsunuz? O halde argümanlarınız hukukun ve idarenin sekülarizasyonu, düşünce ve örgütlenme özgürlüğü, kadın hakları ve evrensel insan hakları olmaz mı? Müslümanları İslam'ın sahte bir din olduğuna, peygamberinin hiç yaşamadığına, bütün kaynaklarının güvenilemez olduğuna iman ettirerek mi sekülerizasyona ikna edeceksiniz?

Ibn Warraq, bihakkın övemediği Batılı eleştirel düşünce yönteminden de yoksundur:

Batı uygarlığını baştan sona kuşatan altın çizgi rasyonalizmdir. Aristoteles'in belirttiği gibi, insan doğası gerçeği bilme çabası içindedir. Bu bilme çabası bilimi ortaya çıkarır; bilim, aklın uygulamaya geçirilmesinden başka bir şey değildir. Zihinsel sorgulayıcılık Batı uygarlığının ayırt edici özelliklerinden biridir. (Ibn Warraq, 2003)

Yirmi birinci yüzyılda bunları yazabilen bir insanın akıldan, bilimden ve "zihinsel sorgulayıcılık"tan ne anladığı meçhuldür. Birilerinin Ibn Warraq'a bu fikirlerin üstünden yüz yıllar geçtiğini, o beğendiği sorgulayıcılık sayesinde, bu felsefeye giriş seviyesinin aşıldığını, Batılı bilim insanlarının, bu eleştirel tutum sayesinde, muazzam bir post-kolonyal eleştiri literatürü inşa ettiğini hatırlatması gerekiyor.

Aslında Ibn Warraq'taki bu üç kusur, yani entelektüel kofluk, eklektizm ve eleştirellikten yoksunluk, bir pozisyonun mecburen savunulmasından kaynaklanıyor: Batının mutlak olarak doğruyu, evrensel ve zamanlar üstü olarak doğruyu temsil ettiğine dair sarsılmaz bir inanç. "...Said'in Batı emperyalizmine, onun sözde kötülüklerine ilişkin duygusal dili..." derken, nasıl da cansiperane aklıyor emperyalizmi! Batı emperyalizminin kötülükleri mi? Zinhar, sözde kötülükleri! Şarkiyatçılık'ta "Birinci Dünya Savaşı öncesinde ve savaş sırasında gizli diplomasi, Yakınşark'ı önce etki alanlarına, ardından da mandalara (ya da işgal edilmiş topraklara) bölmekte kararlıydı." diyen Said'e (1978) karşı, Batı emperyalizminin masumluğunu ispatlamak üzere, akıl dışı iddialarda bulunmaktan kaçınmaz: “Osmanlı İmparatorluğu'nun kendi isteğiyle girdabın içine dalması, doğrudan topraklarını genişletmeye ve itibar kazanmaya yönelik emperyalist Osmanlı politikasını yansıtıyordu daha çok." (Ibn Warraq, 2003) Batının mutlak doğruluğuna iman etmek, onunla duygusal bir bağ kurmasına da yol açmış Ibn Warraq'ın: Zavalıı Fransızların Mısır'da "onur kıııcı bir biçimde saf dışı edilmeleri" (Ibn Warraq, 2003) bile yüreğine dert olmuş! Nasıl olur da saf dışı edilirler, hem de "Mısır bütün modernliğini Napolyon'a borçlu[yken]". (Ibn Warraq, 2003)

Bu katı pozisyonun savunulması adına, kavgada her yol mubahtır. Ibn Warraq muarızına ahlaksızca saldırır: "Pek moda olan cinsellik merkezli bir ruhsal çözümlemeye kalkışacak 
olsam, şunu sormaktan alamazdım kendimi: 'Said hangi cinsel kaygı özürünü gizlemeye çalışıyor? Kahire'deki İngilizce hazırlık okulunda ne yaptılar acaba Said'e?'" (Ibn Warraq, 2003) Başından beri işaret ettiğimiz ortaokul zekâ seviyesine ve bir ergenin espri anlayışına uygun bu ahlaksızlığı, bu kısa makalede iki kez yineler Ibn Warraq: "Sahi acaba ne yaptılar Said'e hazırlık okulunda?" (Ibn Warraq, 2003) Ibn Warraq'ın ahlaksız hücumundan sadece Said değil, onun övgüsüne mazhar olan Massignon da payını alır. Ibn Warraq sözde ahlakçılık yaparak, onu da mahkûm ettiğini düşünür: "Son olarak, Massignon, Said'in düşündüğü gibi Hristiyan tinselliğinin kusursuz bir örneği olmaktan uzaktı, çünkü Massignon'un Doğudaki ilgi alanlarından biri, şehir şehir dolaşıp erkek fahişeler aramaktı: 'Çöküş içindeki Batı'da yapmaya cesaret edemediği bir şey!" (Ibn Warraq, 2003) Böyle bir zihinden bilimsel ahlak beklemek de beyhude bir uğraştır. Culture and Imperialism'de Jane Austen'nın Mansfield Park'ına karşı işlediği "günah"ı, hemen bir yıl sonra Representations of the Intellectual: The 1993 Reith lectures'da çıkaran Said'i mahcup edebilmek uğruna, Ibn Warraq 2007 yılında "Jane Austen and Slavery" başlıklı bir makale yazar.

\section{Tarif}

Meriç'in "sudaki aksinden tiksinen narsist" tanımında zorunlu olarak içerilen "bakış" ile Tierney'in "Batılının içselleştirilmiş bakışı" ve "Batılı gözlük" ifadelerindeki "bakış", kastımızın hemen hemen aynı olduğunu gösteriyor. Hazır, şu güzel "bakış", "göz" ve "gözlük" metaforlarını hatırlamışken, bizim self-kolonizasyon dediğimiz şeyi bu metaforlarla, bir cümleyle tarif etmeye çalışalım: Self-kolonyalist, oto-oryantalist gibi Batılı bir gözlükle kendi toplumuna gözlerini dikmez; aksine kendi toplumunun Batılı bir gözle bakıldığında oluşturulabilecek en aşırı ve kabul edilemez imgesini gösterebilen bir gözlük imal ederek, bunu Batılıların gözüne takmaya çalışır.

\section{Sonuç}

Self-kolonyalistlerin maluliyetlerini teşkil eden entelektüel kofluk, eklektizm ve eleştirel düşünceye uzaklık gibi kusurlar, giderilebilir olmaktan uzaktır. O yüzden, eleştirilerimiz sayesinde kendilerini yeniden üretebilmesinden korkmadan, onları rahatlıkla eleştirebiliyoruz. Çünkü bu kusurları giderilebilseydi, Doğunun karşısında "mutlak doğru" olan Batının yanında yer almaları, Doğu ve Batıyı böylesi özcü bir mutlaklıkla ayırmaları, kısaca olduğu şey olarak kalmaları mümkün olmayacaktı. Eğer bir nebze olsun eleştirel bakıştan nasiplenebilselerdi, tüm bir post-kolonyal literatürü görmezden gelemeyecek ve bu cahil cesaretiyle Said'e saldıramayacaklardı. Ibn Warraq, Said'e saldırmasının nedenini makalenin başında pek güzel açıklıyor:

Araplarla Müslümanlar açısından özeleştiriyi ve özellikle Batıda İslam'ın eleştirilmesini son derece zorlaştıran şey, Edward Said'in Şarkiyatçılık'ının bütünüyle olumsuz etkisidir. Bu yapıt bütün bir Arap kuşağına kendine acıma sanatını -'kötü emperyalistler, Irkçılar ve Siyonistler olmasa, gene olağanüstü bir durumda olurduk'- öğretmiş; 1980 'li yılların İslamcı köktendinci kuşağını yüreklendirmiş; İslam'a yönelik her tür eleştiriyi sessizliğe mahkûm etmiş, hatta bulgularıyla İslami duyarlıkları incitebileceklerinden korkan ve 'Şarkiyatçı'lıkla yaftalanma riskini göze alamayan seçkin İslam bilginlerinin araştırmalarını durma noktasına getirmiştir. Şarkiyatçıı'ın saldırgan tonunu 'entelektüel terörizm' olarak adlandırıyorum, çünkü bu ton insanları, ussal savlar ya da tarihsel çözümleme yoluyla değil, ahlaki bir zirveden ırkçılık, emperyalizm, Avrupamerkezcilik suçlamaları serperek ikna etmeye çalışı; Said'le görüş ayrıı̆ı̆ı içindeki herhangi bir kişi pek çok hakarete maruz kalır. (Ibn Warraq, 2003) 
Görüldüğü üzere Said'in eseri self-kolonyalistlerin önünde aşılmaz bir dağ misali dikiliyor. Ibn Warraq ise efendilerine sesleniyor: Doğuya ve bilhassa Müslümanlara karşı emperyalist politikalarınızı uygularken, şu Said "belası" yüzünden, bir süredir ideolojik destekten yoksun kaldınız. Âlimleriniz bilimsel çalışma adı altında, eskisi gibi lojistik destek üretmekten çekinir oldu. Hatta sizlerden bazıları, onların da bir medeniyete sahip olabileceğini falan düşünmeye başladı. Korkmayın! Bendeniz bu — dağı aşmakta olmasa bile— dağın etrafından dolanmada, bir "yerli" olarak size kılavuzluk, hatta öncülük yapacağım. Beni takip edin!

Muhtemelen Ibn Warraq, Hristiyan bir kökenden gelen sekülarist bilim insanı kisvesindeki "Islamcı terörist" Edward Said'i böylelikle alt ettikten sonra, hempası Richard Dawkins'in başına musallat olan bir belayı defetmeye çalışacaktır: Marksist eleştirmen kisvesinde dolaşan ünlü İslam âlimi el-Terry bin Eagleton!

\section{Kaynakça}

Barthes, R. (1989). Leçon. Paris: Seuil.

Said, E. (1993). Culture and Imperialism. New York: Knopf.

Said, E. (1995). Entelektüel: Sürgün, Marjinal, Yabancı. İstanbul: Ayrıntı.

Said, E. (2000). Haberlerin Ağında İslam. İstanbul: Babil.

Said, E. (1978). Orientalism. New York: Pantheon Books.

Said, E. (1994). Representations of the intellectual: The 1993 Reith lectures. New York: Pantheon Books.

Tierney, R. (2005). The Colonial Eyeglasses of Nakajima Atsushi. Japan Review, 17, 149-196.

Warraq, I. (2007). Defending the West: A Critique of Edward Said's Orientalism. Amherst, New York: Prometheus Books.

Warraq, I. (2007, Temmuz). Jane Austen and Slavery. New English Review: http://www.newenglishreview.org/ Ibn_Warraq/Jane_Austen_and_Slavery adresinden 6 Şubat 2010 tarihinde edinilmiştir.

Warraq, I. (2007, 10 Kasım). Kuran eleştirisine tepkiler abartılı (mı?) [Mülakat D. Schönlebe tarafından]. Qantara. de: http://tr.qantara.de/webcom/show_article.php/_c-674/_nr-117/i.html adresinden 6 Şubat 2010 tarihinde edinilmiştir.

Warraq, I. (2003). Said ve Saidciler ya da Üçüncü Dünya Entelektüel Terörizmi. Cogito, 37, 289.

Warraq, I. (1995). Why I Am Not a Muslim. Amherst, New York: Prometheus Books. 